\title{
Arginine Relieves the Inflammatory Response and Enhances the Casein Expression in Bovine Mammary Epithelial Cells Induced by Lipopolysaccharide
}

\author{
Tianyou Wu, ${ }^{1}$ Chao Wang, ${ }^{2}$ Luoyang Ding, ${ }^{1}$ Yizhao Shen, ${ }^{1}$ Huihui Cui, \\ Mengzhi Wang, ${ }^{1}$ and Hongrong Wang ${ }^{1}$ \\ ${ }^{1}$ Laboratory of Metabolic Manipulation of Herbivorous Animal Nutrition, College of Animal Science and Technology, \\ Yangzhou University, Yangzhou 225009, China \\ ${ }^{2}$ Cell Signaling Group, School of Pathology and Laboratory Medicine, The University of Western Australia, \\ M Block QEII Medical Center, Monash Avenue, Nedlands, WA 6009, Australia
}

Correspondence should be addressed to Hongrong Wang; hrwang@yzu.edu.cn

Received 11 November 2015; Accepted 24 February 2016

Academic Editor: Teresa Zelante

Copyright (C) 2016 Tianyou Wu et al. This is an open access article distributed under the Creative Commons Attribution License, which permits unrestricted use, distribution, and reproduction in any medium, provided the original work is properly cited.

\begin{abstract}
As one of functional active amino acids, L-arginine holds a key position in immunity. However, the mechanism that arginine modulates cow mammary inflammatory response in ruminant is unclear. Therefore, this study was conducted to investigate the effects of L-arginine on inflammatory response and casein expression after challenging the bovine mammary epithelial cells (BMECs) with lipopolysaccharide (LPS). The cells were divided into four groups, stimulated with or without LPS (10 $\mu \mathrm{g} / \mathrm{mL})$ and treated with or without arginine $(100 \mu \mathrm{g} / \mathrm{mL})$ for $12 \mathrm{~h}$. The concentration of proinflammatory cytokines, inducible nitric oxide synthase (iNOS), mammalian target of rapamycin (mTOR), and Toll-like receptor 4 (TLR4) signaling pathways as well as the casein was determined. The results showed that arginine reduced the LPS-induced production like IL- $1 \beta$, IL-6, TNF- $\alpha$, and iNOS. Though the expression of NF- $\kappa \mathrm{B}$ was attenuated and the mTOR signaling pathway was upregulated, arginine had no effect on TLR4 expression. In addition, our results show that the content of $\beta$-casein and the total casein were enhanced after arginine was supplemented in LPS-induced BMECs. In conclusion, arginine could relieve the inflammatory reaction induced by LPS and enhance the concentration of $\beta$-casein and the total casein in bovine mammary epithelial cells.
\end{abstract}

\section{Introduction}

Today's intensive dairy cow management systems encourage the inclusion of large amounts of cereal grains in the diets of lactating dairy cows to support high milk yield and enhance cost efficiency. However, overfeeding a high grain diet is associated with subacute rumen acidosis (SARA) which is characterized by rapid and prolonged decrease in ruminal $\mathrm{pH}$ and the release of lipopolysaccharide (LPS) due to the increase in lyses of gram-negative bacteria cell in the rumen [1-3]. The LPS accumulated in the rumen can translocate into the peripheral blood circulation and invade the bovine mammary tissue after breaking the Milk-Blood Barrier [4]. Once the LPS entered in the udder, proinflammatory cytokines such as IL- $1 \beta$, IL- 6 , and TNF- $\alpha$ would be excessively produced. Consequentially, local mammary inflammation events were induced via LPS/TLR4 signaling pathways [5-7]. Indeed, normal milk secretion from mammary epithelial cells was disrupted, and the casein expression was also declined $[8,9]$.

It is widely accepted that arginine serves as a functional amino acid [10]. Except for protein synthesis, arginine holds a key position in both innate and acquired immunity as well. It is the sole substrate for production of nitric oxide (NO) and the precursor for synthesis of polyamines, proline, and agmatine [11] which are important immune molecules. Arginine exerts its immunologic function through regulating the functional activity, proliferation, and apoptosis of immune cells [12]. Additionally, emerging evidence showed that arginine boosts immune function via regulation of 
mTOR signal pathways $[13,14]$. Investigations from monogastric animals and poultry also have indicated that dietary supplementation or intravenous administration of arginine has a positive effect on inflammation and immune response induced by LPS. Zhu et al. claimed that arginine supplementation protected and enhanced weaned pigs' intestinal mucosal immune barrier function and maintains intestinal integrity after E. coli LPS challenged [15]. Moreover, Tan et al. found that diet supplementation with $1.42 \%$ arginine attenuated the overexpression of proinflammatory cytokines in broiler chickens [16]. However, little research has been conducted in the dairy cattle.

Bovine mammary epithelial cells (BMECs) are the main sites for milk protein synthesis and secretion. They are the first line of defense against bacteria pathogenicity as well [17]. Our previous in vitro studies showed that arginine increased the synthesis of casein in BMECs through activation of mammalian targets of rapamycin (mTOR) and Janus Kinase Signal Transducers 2 and activators of transcription 5 signaling pathways [18]. The objective of this study is to explore whether arginine can relieve the inflammatory response and enhance the expression of casein in BMECs induced by LPS.

\section{Materials and Methods}

2.1. Cells Isolation and Culture. All procedures including animals in our study were approved by the Yangzhou University Animal Care and Use Committee of Jiangsu Province, China (SCXK, protocol \#2012-0004). Three multiparous dairy cows $(513.67 \pm 13.05 \mathrm{Kg}$, day $200.33 \pm 5.86$ of lactation) were obtained from the Experimental Farm of Yangzhou University. After milking in the morning, tissue sample was taken by biopsy [19]. The sample was placed in DMEM/F12 (1:1) medium supplemented with the antibiotic-antimycotic mix (Sigma-A5955) and rinsed several times with PBS including $100 \mathrm{IU} / \mathrm{mL}$ mycillin to make sure there was no milk and blood contained. The tissue was then minced to $1 \mathrm{~mm}^{3}$ pieces and digested by $0.5 \%(\mathrm{w} / \mathrm{v})$ collagenase II at $38^{\circ} \mathrm{C}$ for $3 \mathrm{~h}$. Epithelial cells were obtained after being filtered through a $74 \mu \mathrm{m}$ strainer and centrifuged for $5 \mathrm{~min}$ at $1811 \mathrm{~g}$. These cells were suspended in $5 \mathrm{~mL}$ growth medium (DMEM/F12 with $10 \%$ FBS, $100 \mathrm{IU} / \mathrm{mL}$ mycillin, $2.5 \mu \mathrm{g} / \mathrm{mL}$ amphotericin $\mathrm{B}, 1 \mu \mathrm{g} / \mathrm{mL}$ prolactin, $1 \mu \mathrm{g} / \mathrm{mL}$ insulin-transferrin, $0.5 \mu \mathrm{g} / \mathrm{mL}$ hydrocortisone, and $10 \mathrm{ng} / \mathrm{mL}$ bovine epithelial growth factor) and then were incubated at $38^{\circ} \mathrm{C}$ in $5 \% \mathrm{CO}_{2}$ in a 25 -square-centimeter plastic culture flask. The growth media were replaced every $48 \mathrm{~h}$. Cells were digested by $0.25 \%$ trypsin and $0.1 \%$ EDTA$2 \mathrm{Na}$ for different times (firstly for 3 minutes and then 5 minutes) to purify the primary epithelial cells when cell number was multiplied and reached $90 \%$ confluence. The identification of pure mammary epithelial cells was carried out according to the methods described in our previous works [18]. The identified mammary epithelial cells were used for this study.

2.2. Experimental Design and Treatment. The 2 nd generation mammary epithelial cells were seeded in 6-well culture plates at the density of $10^{6}$ per hole for gene expression analysis and seeded in $10 \mathrm{~cm}$ cell culture dish at $10^{7}$ cells per dish for protein concentration analysis. The cells were cultured at $38^{\circ} \mathrm{C}$ with $5 \% \mathrm{CO}_{2}$ in humidified incubator. The growth media were changed with DMEM/F12 medium when cells were adherent to the vessel surface. Through a $16 \mathrm{~h}$ incubation, cells were divided into four groups and the medium was replaced with different medium as follows:

(1) Control, DMEM/F12 medium;

(2) Arginine treatment, DMEM/F12 medium supplemented with $100 \mu \mathrm{g} / \mathrm{mL}$ L-arginine;

(3) LPS treatment, DMEM/F12 medium supplemented with $10 \mu \mathrm{g} / \mathrm{mL}$ LPS from E. coli 055:B5 (SigmaAldrich, number L2880);

(4) LPS with arginine treatment, DMEM/F12 medium supplemented with both $10 \mu \mathrm{g} / \mathrm{mL}$ LPS and $100 \mu \mathrm{g} /$ $\mathrm{mL}$ L-arginine.

2.3. RNA Extraction and Gene mRNA Expression Analysis. After culturing for 12 hours, the total RNA was extracted with TRIzol (Invitrogen) reagent and its quantity and integrity were evaluated with a NanoDrop 1000 spectrophotometer (NanoDrop Technologies, Wilmington, DE, USA). RNA samples were reverse-transcribed using PrimeScript 1st Strand cDNA Synthesis Kit (TaKaRa Code: D6110A, TaKaRa Biotechnology (Dalian) Co., Ltd., Dalian, China) according to the manufacturer's instructions. The real-time PCR was performed with a Bio-Rad IQ5 Real-Time PCR (Bio-Rad Laboratories, Inc., Hercules, CA, USA), using SYBR Premix Ex Taq II Kit (TaKaRa Code: DRR081A, TaKaRa Biotechnology (Dalian) Co., Ltd., Dalian, China). The protocol in detail was described in our previous works [18]. Primers for target and internal reference gene ( $\beta$-actin) were designed with Primer 5.0 and synthesized by Shanghai Sangon Biological Engineering Technology \& Services Co., Ltd. (China). The information of primers was displayed in Table 1.

2.4. Protein Isolation and Total Protein Concentration Determination. After $12 \mathrm{~h}$ incubation with challenge medium, total protein was extracted using RIPA lysis buffer (Beyotime, number P0013B, Beyotime Biotechnology, Shanghai, China) which consisted of a 1:100 dilution of phenylmethylsulfonyl fluoride (Sigma) and cocktail (Sigma, number P8340). The concentrations of the total protein were determined with BCA assay kits (Beyotime, number P0010).

2.5. Western Blot Analysis. Protein sample was boiled at $100^{\circ} \mathrm{C}$ for $5 \mathrm{~min} ; 30 \mu \mathrm{g}$ of total protein per lane was resolved by SDS-PAGE and then transferred to polyvinylidene difluoride (PVDF) membrane (Pall Corporation, Port Washington, NY, USA; \# 66543) by using the wet transfer TransBlot assembly (Bio-Rad). Membranes were blocked in Tris-buffered saline (TBS-T; $50 \mathrm{mM}$ Tris, $\mathrm{pH}$ 7.6, $150 \mathrm{mM} \mathrm{NaCl}$, and 1\% Tween 20) which contains $5 \%$ (w/v) Bovine Serum Albumin (BSA) for $2 \mathrm{~h}$ at room temperature with gentle agitation. The membranes were then incubated in TBS-TV (TBS-T; $50 \mathrm{mM}$ Tris, $\mathrm{pH} 7.4,150 \mathrm{mM} \mathrm{NaCl}, 1 \%$ Tween 20, and $100 \mathrm{mM}$ sodium vanadate) with $5 \%$ BSA containing antibodies to $\beta$ actin (Beyotime, number AA128), TLR4 (Novus Biologicals, 
TABLE 1: Primers utilized for quantitative real-time PCR analysis.

\begin{tabular}{|c|c|c|c|c|}
\hline Gene & Forward primer & Reverse primer & $\begin{array}{l}\text { Product } \\
\text { size (bp) }\end{array}$ & $\begin{array}{c}\text { Amplification } \\
\text { efficiency }\end{array}$ \\
\hline$\beta$-Actin & CCTGCGGCATTCACGAAACTAC & ACTCCTGCTTGCTGATCCACATC & 273 & $96.75 \%$ \\
\hline TLR-4 & CGGCACAGACAGAGGGTTAT & GGTCCAGCATCTTGGTTGAT & 240 & $104.15 \%$ \\
\hline $\mathrm{NF}-\kappa \mathrm{B}$ & CССTTCCAAGTTCCCATAGAA & CTCCCAGAGTTCCGATTCAC & 197 & $93.55 \%$ \\
\hline iNOS & GGACTTGGCTACGGAACTGG & GGTGAAGCGTGTCTTGGAAA & 257 & $89.21 \%$ \\
\hline IL-1 $\beta$ & CCTCCGACGAGTTTCTGTGT & AAAGCTCATGCAGAACACCA & 161 & $93.51 \%$ \\
\hline IL-6 & GCTCTCATTAAGCGCATGGT & AGCAAATCGCCTGATTGAAC & 172 & $95.38 \%$ \\
\hline TNF- $\alpha$ & CCTGCCAATGTTTCCAGACT & GGCAGCCCTTAGTTTGTGTC & 183 & $99.71 \%$ \\
\hline $\mathrm{PI} 3 \mathrm{~K}$ & GATGCTACCTTACGGCTGCT & CGGCACAGGATAGGGTAAAC & 215 & $94.39 \%$ \\
\hline $\mathrm{AKT}$ & CACCATTACGCCACCTGAC & CACTCAAACGCATCCAGAAA & 233 & $101.27 \%$ \\
\hline mTOR & CATGTGCGAACACAGCAACA & TGCCTTTCACGTTCCTCTCC & 149 & $94.59 \%$ \\
\hline
\end{tabular}

number NBP2-24538), NF- $\kappa$ B p65 (CST, \#4764), p-NF- $\kappa \mathrm{B}$ p65 (CST, \#3033), PI3K p85 (CST, \#4292), p-PI3K p85 (CST, \#4228), AKT (CST, \#9272), p-AKT (Ser473) (CST, \#4060), mTOR (CST, \#2972), and p-mTOR (Ser2448) (CST, \#5536) with gentle agitation at $4^{\circ} \mathrm{C}$ overnight. After incubating with primary antibody, the membranes were washed and incubated with HRP-conjugated secondary antibodies (Beyotime, number A0208) in TBS-TV for $1 \mathrm{~h}$ at room temperature. The bolts were washed and then developed with Super ECL Plus reagent (Apply Technologies Inc., number P1010, Beijing, China). The $\beta$-actin, a housekeeping gene, was used as a positive loading control. The images were captured using a FluorChem HD2 (Protein Simple, USA). The intensities of the bands were measured with Image-ProPlus 6.0 software.

2.6. Cytokine Assay. Concentrations of IL-1 $\beta$, IL-6, and TNF$\alpha$ from cellular culture supernatants were determined by Enzyme Immunometric Assay (ELISA) kits (from R\&D Systems, \#DY401, DY8190, MTA00; assay length was 15.6$1000 \mathrm{pg} / \mathrm{mL}, 15.6-1000 \mathrm{pg} / \mathrm{mL}, 10.9-700 \mathrm{pg} / \mathrm{mL})$. The examination steps in detail were carried out as the manufacturer's protocol described. The optical density of each well was read at $450 \mathrm{~nm}$.

2.7. Measurement of Nitric Oxide (NO) Content. Cellular culture supernatants $(0.5 \mathrm{~mL})$ were gathered separately at $1 \mathrm{~h}$ and $12 \mathrm{~h}$ after cells were incubated with challenge medium. The amount of NO secreted in supernatants was determined with the NO detection kit (Beyotime, number A0208). Briefly, $100 \mu \mathrm{L}$ of supernatants or standard $\mathrm{NaNO}_{2}$ was mixed with $100 \mu \mathrm{L}$ Griess reagent in a 96-well plate and incubated in room temperature for $15 \mathrm{~min}$. NO concentration was determined based on the standard curve by measuring the absorbance at $570 \mathrm{~nm}$ on a microplate reader.

2.8. Measurement of Casein Content. The content of $\alpha-, \beta-$, and $\kappa$-casein was measured by ELISA kits (from R\&D, Minneapolis, MN, USA, divided by Xinyu Company, Shanghai, China, \# CK-E94189B, CK-E94192B, CK-E94193B). Their assay length was $20-320 \mu \mathrm{g} / \mathrm{mL}, 25-400 \mu \mathrm{g} / \mathrm{mL}$, and $12.5-$ $200 \mu \mathrm{g} / \mathrm{mL}$. The examination steps in detail were carried out as the manufacturer's protocol described. The optical density of each well was read at $450 \mathrm{~nm}$

2.9. Statistical Analysis. All data sets of this study were expressed as the mean \pm SEM of three independent experiments. One-way analysis of variance (SPSS V16.0 software; SPSS Inc., Chicago, IL) was performed for statistical analysis. $P<0.05$ was considered significant difference.

\section{Results}

3.1. Arginine Reduced LPS-Induced Proinflammatory Cytokines Production in BMECs. Relative mRNA expression levels for IL-1 $\beta$, IL-6, and TNF- $\alpha$ are illustrated in Figure 1. In comparison with the contrast quarter, addition of LPS dramatically increased the mRNA abundance of IL-1 $\beta$ (6.7fold higher; $P<0.001)$, IL-6 (3.1-fold higher; $P<0.001$ ), and TNF- $\alpha$ (2.0-fold higher; $P<0.001)$. And addition of arginine inhibited mRNA levels of IL- $1 \beta$ (2.4-fold lower; $P<0.001$ ), IL-6 (1.7-fold lower; $P<0.001$ ), and TNF- $\alpha$ (1.4-fold lower; $P<0.05)$ in cells induced with LPS, compared with LPS quarter. The effect of arginine on the protein expression of IL- $1 \beta$, IL- 6 , and TNF- $\alpha$ in LPS-activated BMECs was similar to that of gene expression (Table 2).

3.2. Arginine Inhibited LPS-Induced NF- $\kappa B$ p 65 Expression but Had No Effect on TLR4 Expression. As shown in Figure 2, in contrast to control quarter, the levels of TLR-4 and NF$\kappa \mathrm{B}$ p65 gene expression were significantly augmented after BMECs were stimulated with LPS $(P<0.01)$. It was worth to highlight that, in contrast to LPS quarter, supplementation of arginine in LPS-induced BMECs significantly decreased $(P<0.05)$ the NF- $\kappa \mathrm{B}$ p65 expression and the level of NF$\kappa \mathrm{B}$ p65 phosphorylation (Figure $2(\mathrm{~b})$ ), but it had no effect $(P>0.05)$ on TLR4 expression (Figure 2(a)).

3.3. Effects of Arginine on iNOS and NO in LPS-Stimulated BMECs. The result of iNOS mRNA abundance and NO content is shown in Figure 3. The mRNA level of iNOS in LPS with arginine treatment effectively towering above in the control quarter $(P<0.01)$ and arginine quarter $(P<0.01)$ 
TABLE 2: Effects of Arginine on protein expression of cytokines in LPS-treated BMECs.

\begin{tabular}{lcccc}
\hline & Con & Arg & LPS & Arg + LPS \\
& $(10 \mu \mathrm{g} / \mathrm{mL})$ & $\begin{array}{c}\text { (DMEM/F12 medium) } \\
(100 \mu \mathrm{g} / \mathrm{mL}+10 \mu \mathrm{g} / \mathrm{mL})\end{array}$ \\
\hline IL-1 $\beta(\mathrm{pg} / \mathrm{mL})$ & $94.51 \pm 0.36^{\mathrm{a}}$ & $116.91 \pm 1.86^{\mathrm{a}}$ & $310.89 \pm 4.84^{\mathrm{c}}$ & $243.15 \pm 16.12^{\mathrm{b}}$ \\
IL-6 $(\mathrm{pg} / \mathrm{mL})$ & $33.61 \pm 0.74^{\mathrm{a}}$ & $34.89 \pm 1.36^{\mathrm{a}}$ & $103.68 \pm 0.92^{\mathrm{c}}$ & $81.70 \pm 0.87^{\mathrm{b}}$ \\
TNF- $\alpha(\mathrm{pg} / \mathrm{mL})$ & $36.78 \pm 1.04^{\mathrm{a}}$ & $38.61 \pm 0.56^{\mathrm{a}}$ & $65.98 \pm 1.13^{\mathrm{c}}$ & $60.36 \pm 3.92^{\mathrm{b}}$ \\
\hline
\end{tabular}

Values are expressed as mean $\pm \operatorname{SEM}, n=3$. Mean with different letters differ $(\mathrm{a}, \mathrm{b}$, or $\mathrm{c}$ ) are significantly different $(P<0.05)$ from each other.

TABLE 3: Effects of arginine on casein synthesis in LPS-treated BMECs.

\begin{tabular}{|c|c|c|c|c|}
\hline & $\begin{array}{c}\text { Con } \\
\text { (DMEM/F12 medium) }\end{array}$ & $\begin{array}{c}\text { Arg } \\
(100 \mu \mathrm{g} / \mathrm{mL})\end{array}$ & $\begin{array}{c}\text { LPS } \\
(10 \mu \mathrm{g} / \mathrm{mL})\end{array}$ & $\begin{array}{c}\text { Arg + LPS } \\
(100 \mu \mathrm{g} / \mathrm{mL}+10 \mu \mathrm{g} / \mathrm{mL})\end{array}$ \\
\hline$\alpha$-Casein $(\mu \mathrm{g} / \mathrm{mL})$ & $164.91 \pm 2.89^{\mathrm{a}}$ & $179.80 \pm 4.33^{\mathrm{b}}$ & $150.49 \pm 6.70^{\mathrm{a}}$ & $155.90 \pm 1.73^{\mathrm{a}}$ \\
\hline$\beta$-Casein $(\mu \mathrm{g} / \mathrm{mL})$ & $75.10 \pm 2.41^{\mathrm{bc}}$ & $82.29 \pm 5.87^{\mathfrak{c}}$ & $52.25 \pm 3.22^{\mathrm{a}}$ & $67.38 \pm 1.62^{\mathrm{b}}$ \\
\hline$\kappa$-Casein $(\mu \mathrm{g} / \mathrm{mL})$ & $24.66 \pm 4.82$ & $27.07 \pm 5.02$ & $19.89 \pm 7.60$ & $21.77 \pm 2.86$ \\
\hline Total $\operatorname{casein}^{1}(\mu \mathrm{g} / \mathrm{mL})$ & $264.67 \pm 0.89^{b}$ & $289.16 \pm 1.39^{c}$ & $222.62 \pm 11.03^{\mathrm{a}}$ & $255.37 \pm 7.83^{\mathrm{b}}$ \\
\hline
\end{tabular}

${ }^{1}$ Total casein $=\alpha$-casein $+\beta$-casein $+\kappa$-casein.

Values are expressed as mean $\pm \operatorname{SEM}, n=3$. Mean with different letters differ $(\mathrm{a}, \mathrm{b}$, or $\mathrm{c})$ are significantly different $(P<0.05)$ from each other.

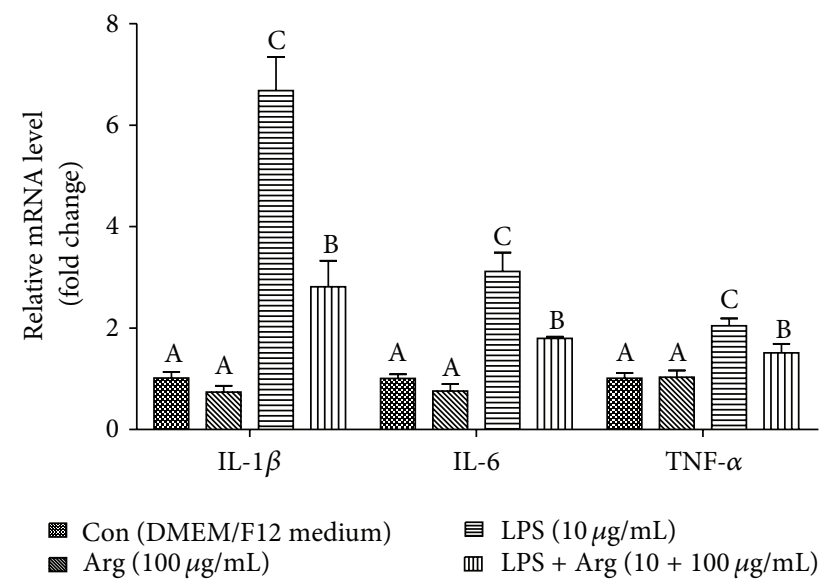

FIGURE 1: The effect of arginine on LPS-induced cytokines mRNA expression in bovine mammary epithelial cells (BMECs). Pure 2nd generation BMECs were starved for $16 \mathrm{~h}$ and then cultured for $12 \mathrm{~h}$ in DMEM/F12 medium containing 0 or $10 \mu \mathrm{g} / \mathrm{mL}$ LPS and 0 or $100 \mu \mathrm{g} / \mathrm{mL}$ Arg. The mRNA levels of IL- $1 \beta$, IL-6, and TNF- $\alpha$ were analyzed using qPCR. $\beta$-Actin was used as an internal reference gene. Data shown are means \pm SEM of three independent experiments. Means with different letters $(\mathrm{A}, \mathrm{B}$, or $\mathrm{C})$ are significantly different $(P<0.05)$ from each other.

was lower than that in the LPS quarter $(P<0.05)$. NO content in the LPS quart and LPS with arginine treatment was dramatically higher than $(P<0.05)$ that in the control quarter and arginine quarter both at $1 \mathrm{~h}$ and $12 \mathrm{~h}$. To our surprise, NO content in the LPS with arginine treatment did not differ $(P>0.05)$ when compared with LPS quarter at $1 \mathrm{~h}$ but was remarkably below $(P<0.01)$ the LPS quarter at $12 \mathrm{~h}$.

3.4. Effects of Arginine on PI3K/AKT/mTOR Signaling Pathway in LPS-Stimulated BMECs. The results of the relative gene expression of PI3K, AKT, and mTOR are shown in Figure 4 . The results showed that the abundance of PI3K and mTOR gene expression in the LPS quarter was markedly lower $(P<0.05)$ than that in the control quarter, yet the abundance of AKT was not significantly different $(P>$ 0.05). Compared with LPS quarter, the mRNA levels of PI3K, mTOR, and AKT in quarter treated with both LPS and arginine were markedly enhanced $(P<0.05)$. We also found that LPS dramatically decreased $(P<0.01)$ the level of $\mathrm{p}$ $\mathrm{mTOR} / \mathrm{mTOR}$, but it had no effect on level of $\mathrm{p}$-PI3K/PI3K and $\mathrm{p}-\mathrm{AKT} / \mathrm{AKT}(P>0.05)$. In contrast to LPS quarter, the level of $\mathrm{p}-\mathrm{AKT} / \mathrm{AKT}$ and $\mathrm{p}-\mathrm{mTOR} / \mathrm{mTOR}$ in cells treated with LPS and arginine was notably augmented $(P<0.01)$, but the level of $\mathrm{p}-\mathrm{PI} 3 \mathrm{~K} / \mathrm{PI} 3 \mathrm{~K}$ was not affected $(P>0.05)$.

3.5. Arginine Increased the $\beta$-Casein and Total Casein Synthesis in LPS-Treated BMECs. The results of the casein concentration are shown in Table 3 . The results showed that the protein expression of $\beta$-casein and total casein in the LPS quarter was significantly lower $(P<0.01)$ than that in the control quarter while $\alpha$-casein had a slight improvement $(P<0.1)$. The levels of $\beta$-casein and total casein synthesis in quarter of LPS with arginine were markedly higher $(P<0.05)$ than quarter of LPS, yet the $\alpha$-casein and $\kappa$-casein synthesis had no significant change $(P>0.05)$.

\section{Discussion}

The ruminant digestive tract harbors numerous gramnegative bacteria that are capable of producing lipopolysaccharide (LPS), but the epithelium acts as a barrier to prevent it from entering into the systemic circulation. However, following tract epithelium barrier failure during grain-induced SARA, LPS can potentially be translocated into the interior of the body, for example, into the blood circulation and lymphatic system. Once translocated, LPS interacts with cells and stimulates the production of proinflammatory mediators such as cytokines, and immune response may expand in the mammary gland. 

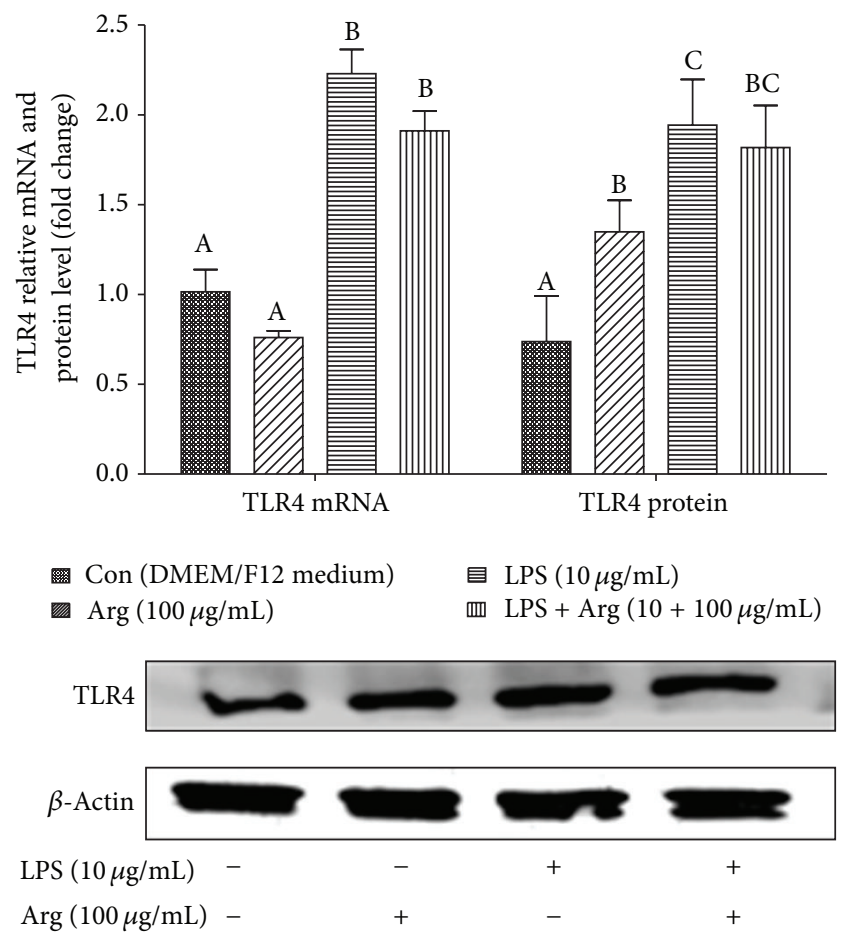

(a)
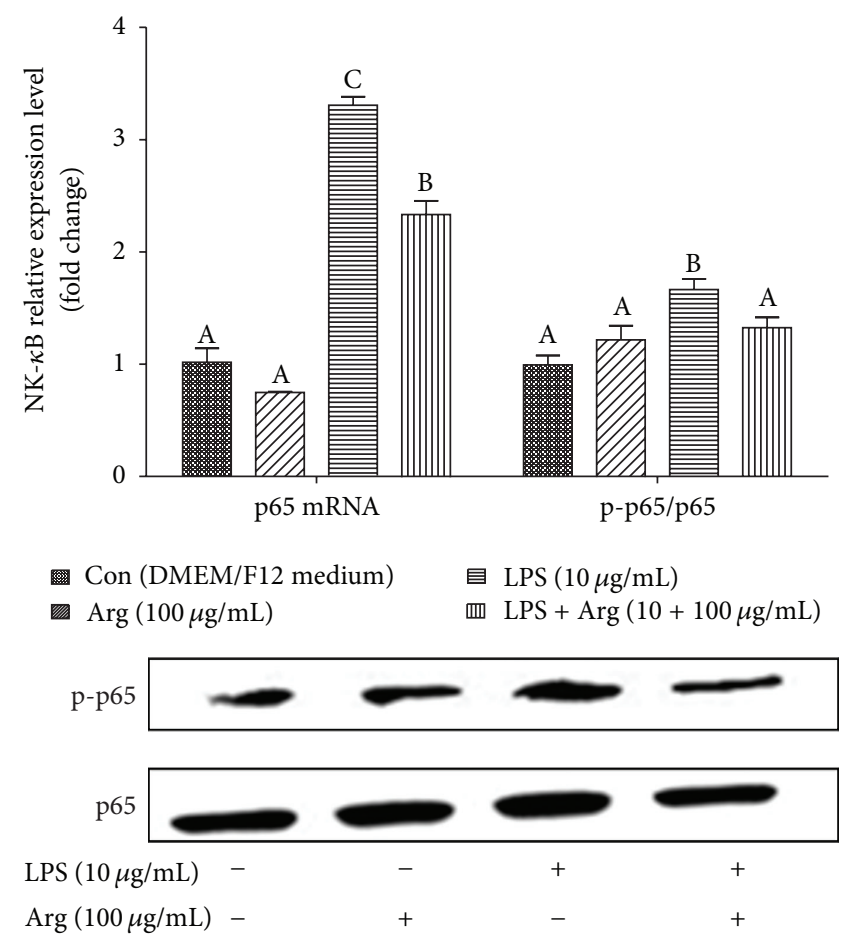

(b)

Figure 2: The effect of Arg on LPS-induced TLR4, NF- $\kappa$ B mRNA, and protein expression in BMECs. Pure 2nd generation BMECs were starved for $16 \mathrm{~h}$ and then cultured in DMEM/F12 medium containing 0 or $10 \mu \mathrm{g} / \mathrm{mL}$ LPS and 0 or $100 \mu \mathrm{g} / \mathrm{mL}$ Arg. After $12 \mathrm{~h}$, the mRNA levels of TLR4 and NF- $\kappa$ B were analyzed using qPCR. Protein expression was analyzed using western bolt. $\beta$-Actin was used as an internal reference. Data shown are mean \pm SEM of three independent experiments. Means with different letters (A, B, or C) are significantly different $(P<0.05)$ from each other.

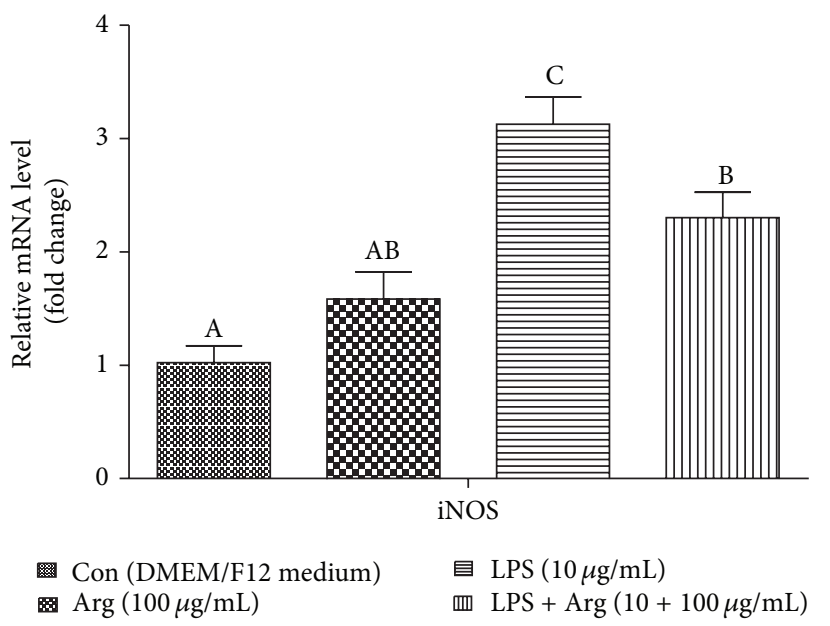

(a)

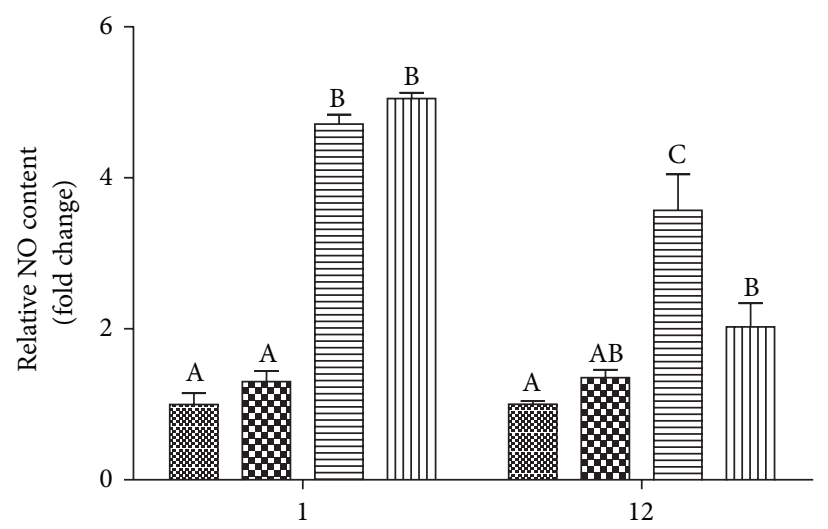

(h)

Con (DMEM/F12 medium)
$\operatorname{Arg}(100 \mu \mathrm{g} / \mathrm{mL})$

目 $\operatorname{LPS}(10 \mu \mathrm{g} / \mathrm{mL})$ 皿 LPS + $\operatorname{Arg}(10+100 \mu \mathrm{g} / \mathrm{mL})$

(b)

FIGURE 3: Effects of Arg on iNOS expression in LPS-treated BMECs. Pure 2nd generation BMECs were starved for $16 \mathrm{~h}$ and then cultured for $12 \mathrm{~h}$ in DMEM/F12 medium containing 0 or $10 \mu \mathrm{g} / \mathrm{mL}$ LPS and 0 or $100 \mu \mathrm{g} / \mathrm{mL}$ Arg. The mRNA levels of iNOS were analyzed using qPCR (a). $\beta$-Actin was used as an internal reference. $0.5 \mathrm{~mL}$ cellular supernatants were gathered at $1 \mathrm{~h}$ and $12 \mathrm{~h}$ separately after cells were incubated with challenge medium. Then NO content in supernatants was analyzed using NO detection kit (b). Data shown are mean \pm SEM of three independent experiments. Means with different letters $(\mathrm{A}, \mathrm{B}$, or $\mathrm{C})$ are significantly different $(P<0.05)$ from each other. 


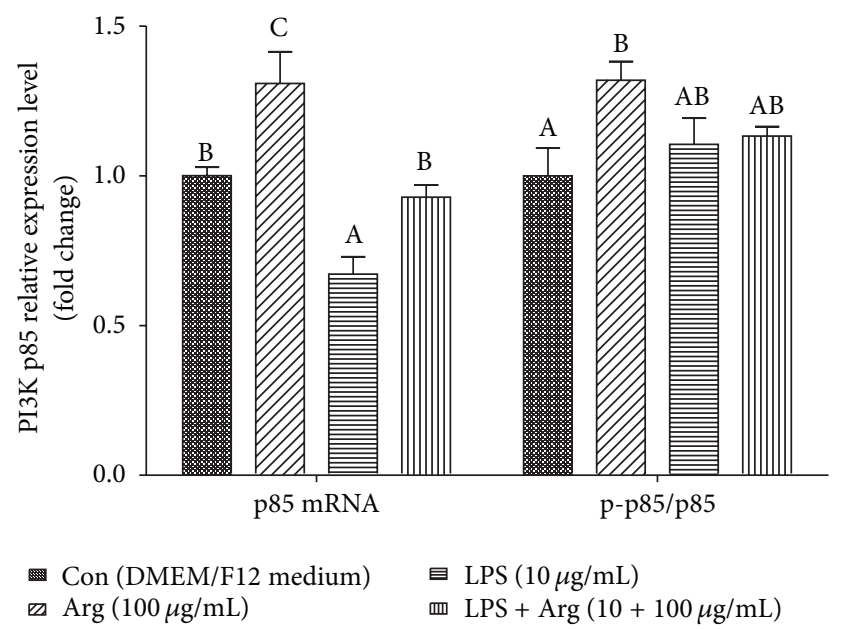

(a)

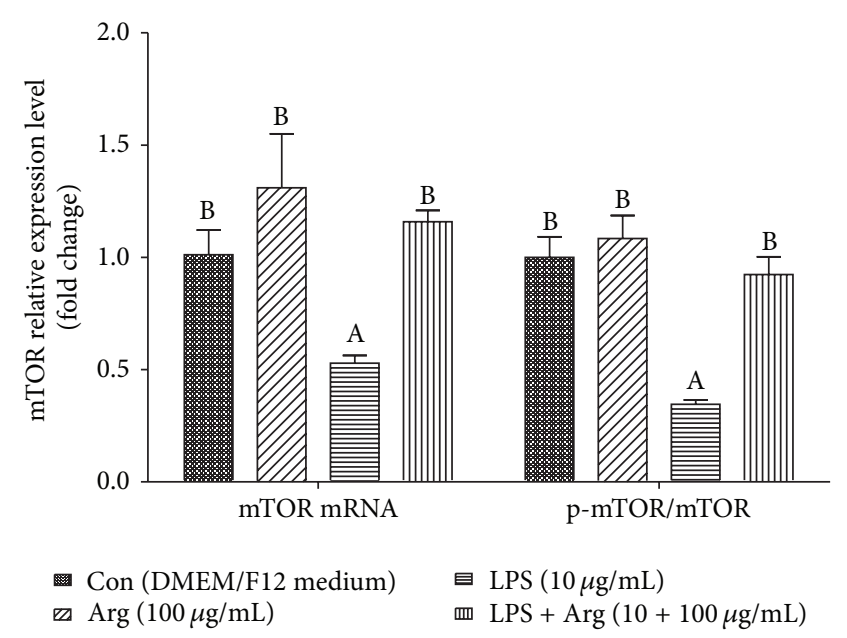

(c)

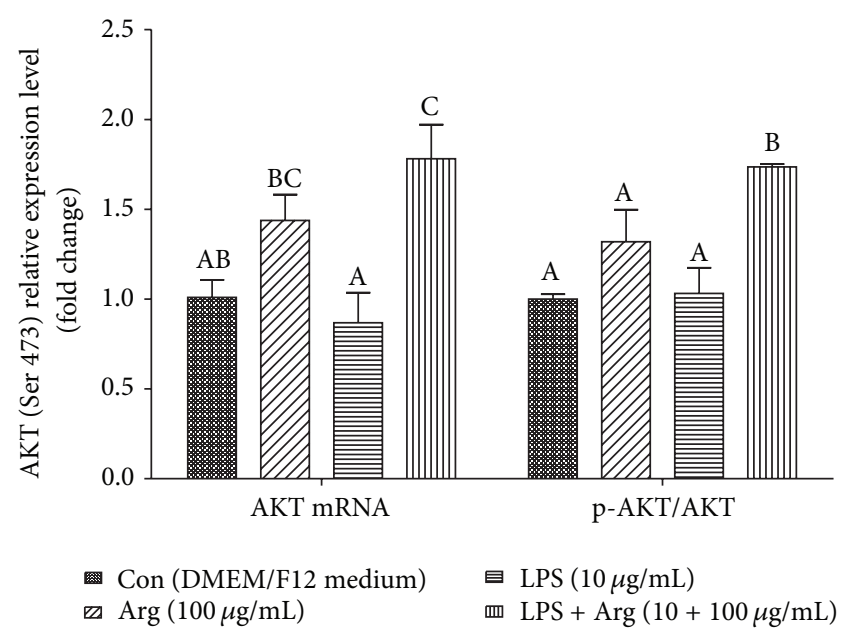

(b)
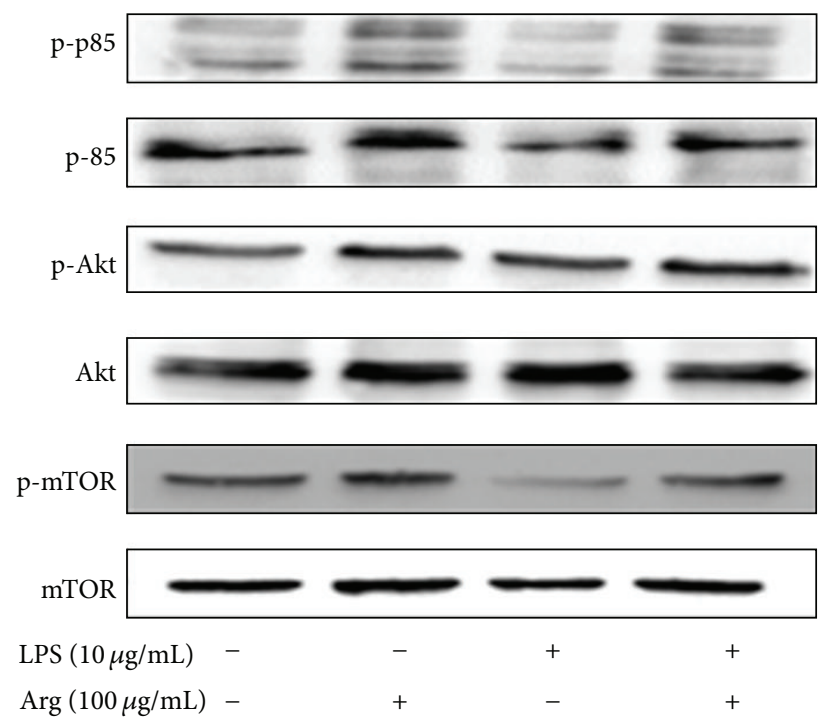

(d)

FIGURE 4: Effect of Arg on the mRNA expression and phosphorylation levels of PI3K/AKT/mTOR signaling pathway in LPS-treated BMECs. Pure 2nd generation BMECs were starved for $16 \mathrm{~h}$ and then cultured for $12 \mathrm{~h}$ in DMEM/F12 medium containing 0 or $10 \mu \mathrm{g} / \mathrm{mL} \mathrm{LPS} \mathrm{and} 0$ or $100 \mu \mathrm{g} / \mathrm{mL}$ Arg. The mRNA levels of PI3K, AKT, and mTOR were analyzed using qPCR. Protein expression and its phosphorylation level were analyzed using western bolt. $\beta$-Actin was used as an internal reference. Data shown are mean \pm SEM of three independent experiments. Means with different letters $(\mathrm{A}, \mathrm{B}$, or $\mathrm{C})$ are significantly different $(P<0.05)$ from each other.

BMECs are the first cells confronted with the bacteria pathogens and are proposed as an important line to defend the bacteria's invasion in the mammary issue $[17,20]$. Evidence indicated that a rapid and strong inflammatory response would be induced when BMECs were challenged with LPS [21]. In the present study, the BMECs were challenged with $10 \mu \mathrm{g} / \mathrm{mL}$ LPS [22] to imitate the inflammatory state that rumen LPS invades the BMECs after injuring the Milk-Blood Barrier. Arginine is a semiessential amino acid for animals. It is insufficient during times of physiologic stress such as wound, histological damage, and inflammation. It has been reported that supplement with arginine in the state of pathologic contributes to strengthening the immunity from disease $[23,24]$. Thus, a following trial that supplemented LPS-induced BMECs with $100 \mu \mathrm{g} / \mathrm{mL}$ arginine [25] was conducted to investigate the effects of arginine on inflammatory response.

It is well known that LPS-induced inflammation events are characterized by eliciting and releasing a large number of proinflammatory cytokines (such as TNF- $\alpha$, IL-1 $\beta$, and IL-6) in macrophages and epithelial cells [26]. These cytokines have a vital role in promoting and regulating the immune function response to bacterial pathogens [27]. And the expression of them, to a certain extent, reflects the magnitude of inflammation response. In this experiment, we confirmed that the concentrations of IL- $1 \beta$, IL- 6 , and TNF- $\alpha$ were remarkably 
increased at $12 \mathrm{~h}$ after BMECs were stimulated with LPS. At the same time, we found that arginine inhibited the secretion of those cytokines. Similar result had been reported by Tan et al. and Calkins et al. [16, 28]. Moreover, Jiang et al. also found that treatment with $100-300 \mu \mathrm{g} / \mathrm{mL}$ arginine in intestine of juvenile carp completely prevents increase of IL- 6 and TNF- $\alpha$ and statistically significant decrease of IL$1 \beta$ mRNA expression [25]. This result indicated that arginine would contribute to attenuating the inflammatory response.

For further insight into the possible mechanisms that arginine suppresses the proinflammatory cytokines expression, we investigated the expression level of TLR4 and NF$\kappa \mathrm{B}$, the vital upstream signaling molecules in regulating the LPS-induced inflammatory response. TLR4, the bacterial LPS receptor, has been shown to be responsible for LPS recognition by cooperating with CD14; it led to the degradation of $\mathrm{I} \kappa \mathrm{B}$ and liberation of $\mathrm{NF}-\kappa \mathrm{B}$ via myeloid differentiation factor 88 (MyD88), IL-1R-associated kinase (IRAK) and TNFR-associated factor 6 (TRAF6). Then NF$\kappa \mathrm{B}$ was translocated into the nucleus and induced transcription of proinflammatory genes after it was activated by phosphorylation [29-31]. Thereby inhibition of NF- $\kappa \mathrm{B}$ activation has been considered as a critical target and effective approach to curb the inflammatory response $[32,33]$. Our study showed that stimulation with LPS augmented the expression of NF- $\kappa \mathrm{B}$ p 65 and the phosphorylation of NF- $\kappa \mathrm{B}$ p65. It prompted that NF- $\kappa \mathrm{B}$ p 65 was active and redound to proinflammatory expression. These results were concordant with previous research by Kim et al. and Verma et al. [4, 34]. Nevertheless, the elevation of NF- $\kappa$ B p 65 expression was completely reversed after supplementing with arginine. It may imply that arginine diminishes the expression of proinflammatory through inhibiting the activation of NF- $\kappa \mathrm{B}$.

Arginine is the sole precursor for the production of $\mathrm{NO}$ by one of the three NO synthases (NOSs). Under normal physiological condition, low concentrations of NO are generated by eNOS (endothelial NOS) and nNOS (neuronal NOS) isoforms. But, in pathological conditions (virus and bacterial infection), high-level NO is synthesized by iNOS to promote the proliferation of immunologic cells and to defend against the pathogenic bacteria. Despite the fact that the high NO concentration in the early stages of inflammation boosts the immune function and inhibits the phosphorylation of NF- $\kappa \mathrm{B}$ [12], it also would lead to uncontrolled tissue injury and may cause inflammatory diseases [35-37]. In this experiment, we gauged the inducible NOS (iNOS) mRNA expression level and the NO content in cell supernatant. Our investigation shows that LPS challenge upregulated the gene expression of iNOS and elevated the contention of NO, which was consistent with previous research [38, 39]. But out of our expectation, arginine administration inhibits the iNOS mRNA expression and declined the NO content at $12 \mathrm{~h}$ in LPS-induced BMECs. Similarly, Xue found that arginine accession increased the activity of eNOS but not iNOS after immature myocardial ischemia-reperfusion injury [40]. Moreover, Colasanti et al. suggested that both sodium nitroprusside (SNP, NO donor) and authentic NO solution are able to inhibit LPS-induced iNOS mRNA expression [41]. That may give evidence to support our observation. In our study, the result that arginine administration downregulated the iNOS mRNA expression and the decline of NO content at $12 \mathrm{~h}$ suggested that arginine may be able to alleviate the inflammatory injury after LPS-induced acute inflammation.

The PI3K/AKT/mTOR pathways have been recognized to be critically involved in cell metabolism, growth, survival, and vesicular transport for a long time $[42,43]$. Recently, a growing body of evidence indicated that this pathway also participated in the innate and adaptive immunity modulation [44-46]. Many known receptors such as cytokine receptors, insulin, insulin-like growth factor I (IGF-1) receptor, and also Toll-like receptors are able to activate the PI3K/AKT/mTOR pathway by enhancing the phosphorylation of PI3K and subsequently AKT and mTOR $[47,48]$. Present data in this study showed that LPS treatment could alter the expression of $\mathrm{PI} 3 \mathrm{~K} / \mathrm{AKT} / \mathrm{mTOR}$ pathway (reduced the mRNA expression of PI3K and mTOR, decreased the level of p-mTOR/mTOR). These findings indicated that the PI3K/AKT/mTOR pathway correlates closely to LPS-induced epithelial cells inflammation events. We also found that arginine administration enhanced the mRNA and its phosphorylation expression of AKT and mTOR (Figure 4). Mendes et al. suggest that the $\mathrm{PI} 3 \mathrm{~K} / \mathrm{AKT} / \mathrm{mTOR}$ could negatively regulate the effects of inflammatory response induced by LPS through blocking $\mathrm{NF}-\kappa \mathrm{B}$ transactivation in vitro model of murine macrophage [49]. Guha and Mackman and Zhang et al. indicated inhibition of PI3K/AKT signaling in human monocytic THP1 cells enhancing NF- $\kappa \mathrm{B}$ activation $[50,51]$. However, the paradoxical results were reported by Xie et al., Lorne et al., and Fortin et al. [46, 52, 53]. They claimed that inhibitors of PI3K and mTOR could remarkably suppress the secretion of cytokines by monocytes and macrophages and human neutrophils. Different cell types and treatments may answer for those paradoxical results. Up to now, there has no direct proof to testify how PI3K/AKT/mTOR pathway accommodates the LPS-induced inflammation in mammary epithelial cells. Therefore, further research is needed to address a series of mechanistic questions in order to increase understanding of arginine involved in the LPS-induced inflammation modulation.

Another purpose of current study is to explore the effects of arginine on casein synthesis in LPS-stimulated BMECs. Bovine lactoprotein is an important component of the human diet. Casein is the major ingredient of milk protein, approximately occupying 80 percent of the total lactoprotein, with $\alpha$-casein $(\alpha-\mathrm{CN})$ comprising $45-55 \%, \beta$ casein $(\beta-\mathrm{CN})$ comprising $25-35 \%$, and $\kappa$-casein $(\kappa-\mathrm{CN})$ comprising $8-15 \%$. The content of casein synthesis is often deemed to the mark of capacity of synthesizing protein and condition of cell function. LPS in bovines' rumen translated to mammary gland after it suffered from SARA, mastitis would be induced, and a series of adverse events would occur, one of which is reduction of casein synthesis [9]. In the current study, we imitated the state that rumen LPS invade the mammary gland by establishing the inflammation model with LPS stimulating the BMECs. We found that LPS markedly declined the $\beta$-casein and the total casein content, but also slightly played down the content of $\alpha-\mathrm{CN}$ and $\kappa-\mathrm{CN}$ in spite of having no significant difference. Parallel results 


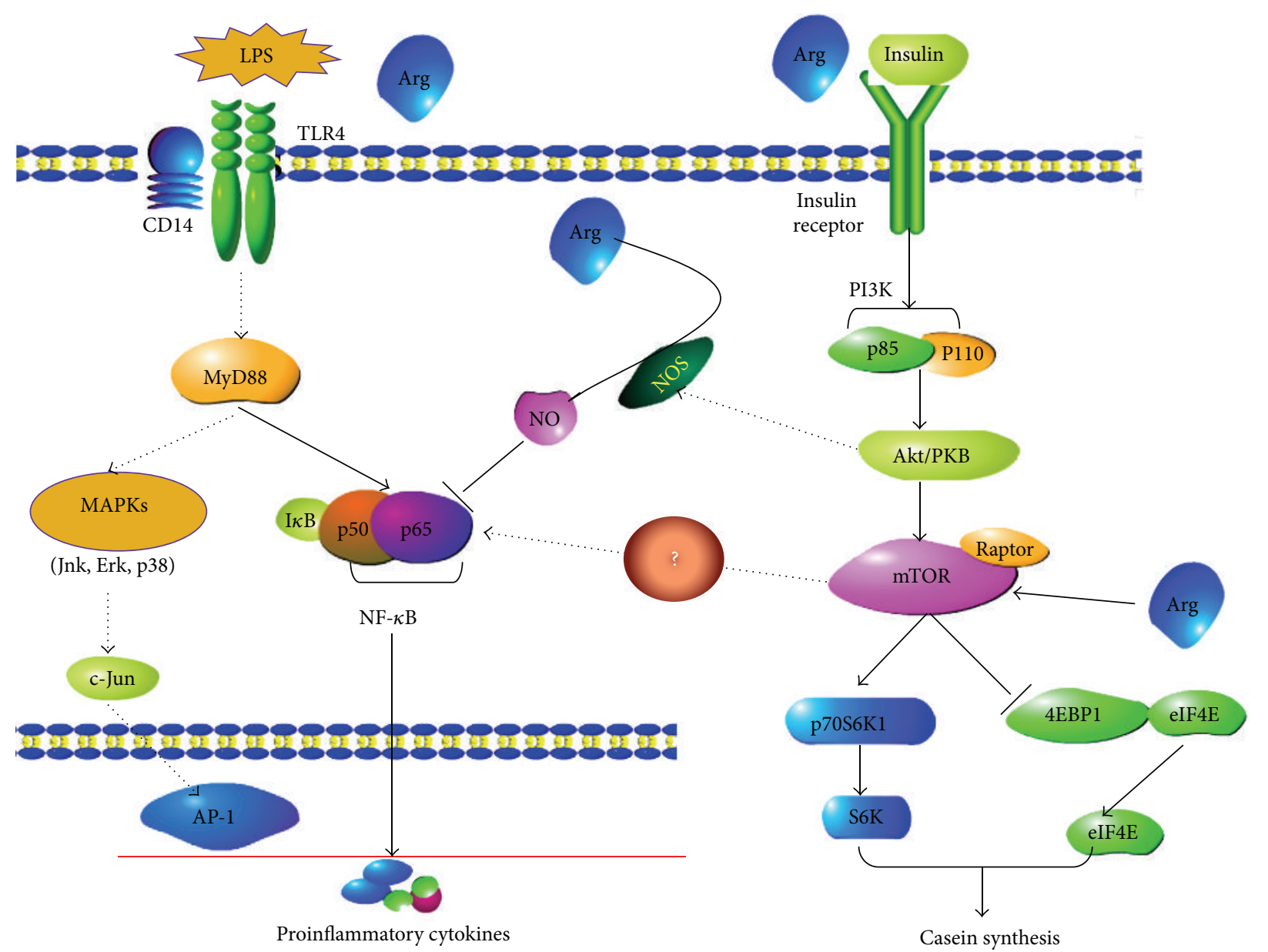

FIGURE 5: The potential mechanism that arginine relieves the inflammatory response and enhances the casein expression in bovine mammary epithelial cells induced by lipopolysaccharide.

were reported by Hinz et al. and Schmitz et al. [54, 55]. We also found that arginine supplementation was able to reverse the tendency of LPS-caused reduction of casein synthesis. Finally, current study demonstrated that arginine is able to enhance the expression of $\beta$-casein and the total casein.

\section{Conclusion}

In summary, the results from the present experiment implied that arginine effectively attenuated LPS-induced bovine mammary epithelial cells inflammatory response by inhibiting NF- $\kappa \mathrm{B}$ signaling pathways. Additionally, arginine may be involved in $\mathrm{Arg} / \mathrm{NO}$ and PI3K/AKT/mTOR pathway. Further, arginine was also able to enhance the $\beta$-casein and the total casein expression in LPS-induced bovine mammary epithelial cells (Figure 5).

\section{Competing Interests}

The authors declare that they have no competing interests.

\section{Authors' Contributions}

The first two authors (Tianyou Wu and Chao Wang) contributed equally to this work.

\section{Acknowledgments}

The authors would like to acknowledge the funding received to conduct this study from the project funded by National Key Basic Research Program of China (973 Program: 2011CB100803), NSFC (Grant no. 31572429), and the Priority Academic Program Development of Jiangsu Higher Education Institutions (PAPD).

\section{References}

[1] Q. Zebeli, D. Mansmann, H. Steingass, and B. N. Ametaj, "Balancing diets for physically effective fibre and ruminally degradable starch: a key to lower the risk of sub-acute rumen acidosis and improve productivity of dairy cattle," Livestock Science, vol. 127, no. 1, pp. 1-10, 2010.

[2] G. Dong, S. Liu, Y. Wu, C. Lei, J. Zhou, and S. Zhang, "Dietinduced bacterial immunogens in the gastrointestinal tract of dairy cows: impacts on immunity and metabolism," Acta Veterinaria Scandinavica, vol. 53, no. 1, article 48, 2011.

[3] F. Klevenhusen, M. Hollmann, L. Podstatzky-Lichtenstein, R. Krametter-Frötscher, J. R. Aschenbach, and Q. Zebeli, "Feeding barley grain-rich diets altered electrophysiological properties and permeability of the ruminal wall in a goat model," Journal of Dairy Science, vol. 96, no. 4, pp. 2293-2302, 2013. 
[4] K.-N. Kim, Y.-J. Ko, H.-M. Yang et al., "Anti-inflammatory effect of essential oil and its constituents from fingered citron (Citrus medica L. var. sarcodactylis) through blocking JNK, ERK and NF- $\kappa$ B signaling pathways in LPS-activated RAW 264.7 cells," Food and Chemical Toxicology, vol. 57, pp. 126-131, 2013.

[5] B. Beutler, K. Hoebe, X. Du, and R. J. Ulevitch, "How we detect microbes and respond to them: the Toll-like receptors and their transducers," Journal of Leukocyte Biology, vol. 74, no. 4, pp. 479-485, 2003.

[6] S. Akira, S. Uematsu, and O. Takeuchi, "Pathogen recognition and innate immunity," Cell, vol. 124, no. 4, pp. 783-801, 2006.

[7] W. V. Ingman, D. J. Glynn, and M. R. Hutchinson, "Inflammatory mediators in mastitis and lactation insufficiency," Journal of Mammary Gland Biology and Neoplasia, vol. 19, no. 2, pp. 161167, 2014.

[8] J. Zhou, G. Dong, C. Ao et al., "Feeding a high-concentrate corn straw diet increased the release of endotoxin in the rumen and pro-inflammatory cytokines in the mammary gland of dairy cows," BMC Veterinary Research, vol. 10, no. 1, article 172, 2014.

[9] N. Isobe, J. Nakamura, H. Nakano, and Y. Yoshimura, "Existence of functional lingual antimicrobial peptide in bovine milk," Journal of Dairy Science, vol. 92, no. 6, pp. 2691-2695, 2009.

[10] G. Wu, "Functional amino acids in nutrition and health," Amino Acids, vol. 45, no. 3, pp. 407-411, 2013.

[11] J. Satriano, "Arginine pathways and the inflammatory response: interregulation of nitric oxide and polyamines: review article," Amino Acids, vol. 26, no. 4, pp. 321-329, 2004.

[12] J. W. Coleman, "Nitric oxide in immunity and inflammation," International Immunopharmacology, vol. 1, no. 8, pp. 1397-1406, 2001.

[13] B. Tan, Y. Yin, X. Kong et al., " L-Arginine stimulates proliferation and prevents endotoxin-induced death of intestinal cells," Amino Acids, vol. 38, no. 4, pp. 1227-1235, 2010.

[14] G. Wu, F. W. Bazer, Z. Dai, D. Li, J. Wang, and Z. Wu, "Amino acid nutrition in animals: Protein synthesis and beyond," Annual Review of Animal Biosciences, vol. 2, pp. 387-417, 2014.

[15] H. L. Zhu, Y. L. Liu, X. L. Xie, J. J. Huang, and Y. Q. Hou, "Effect of L-arginine on intestinal mucosal immune barrier function in weaned pigs after Escherichia coli LPS challenge," Innate Immunity, vol. 19, no. 3, pp. 242-252, 2013.

[16] J. Tan, Y. Guo, S. Eicher, and T. Applegate, "Dietary L-arginine supplementation modulates lipopolysaccharide-induced systemic inflammatory response in broiler chickens," Poultry Science, vol. 92, 2013.

[17] Y. Strandberg, C. Gray, T. Vuocolo, L. Donaldson, M. Broadway, and R. Tellam, "Lipopolysaccharide and lipoteichoic acid induce different innate immune responses in bovine mammary epithelial cells," Cytokine, vol. 31, no. 1, pp. 72-86, 2005.

[18] M. Wang, B. Xu, H. Wang, D. Bu, J. Wang, and J.-J. Loor, "Effects of arginine concentration on the in vitro expression of casein and mTOR pathway related genes in mammary epithelial cells from dairy cattle," PLoS ONE, vol. 9, no. 5, Article ID e95985, 2014.

[19] M. Bionaz and J. J. Loor, "Identification of reference genes for quantitative real-time PCR in the bovine mammary gland during the lactation cycle," Physiological Genomics, vol. 29, no. 3, pp. 312-319, 2007.

[20] C. Zbinden, R. Stephan, S. Johler et al., "The inflammatory response of primary bovine mammary epithelial cells to Staphylococcus aureus strains is linked to the bacterial phenotype," PLoS ONE, vol. 9, no. 1, Article ID e87374, 2014.
[21] J. Günther, D. Koczan, W. Yang et al., "Assessment of the immune capacity of mammary epithelial cells: comparison with mammary tissue after challenge with Escherichia coli," Veterinary Research, vol. 40, no. 4, article 31, 14 pages, 2009.

[22] A. Rabot, O. Wellnitz, H. H. D. Meyer, and R. M. Bruckmaier, "Use and relevance of a bovine mammary gland explant model to study infection responses in bovine mammary tissue," Journal of Dairy Research, vol. 74, no. 1, pp. 93-99, 2007.

[23] L. Shan, B. Wang, G. Gao, W. Cao, and Y. Zhang, "L-Arginine supplementation improves antioxidant defenses through Larginine/nitric oxide pathways in exercised rats," Journal of Applied Physiology, vol. 115, no. 8, pp. 1146-1155, 2013.

[24] B. Porro, S. Eligini, F. Veglia et al., "Nitric oxide synthetic pathway in patients with microvascular angina and its relations with oxidative stress," Oxidative Medicine and Cellular Longevity, vol. 2014, Article ID 726539, 9 pages, 2014.

[25] J. Jiang, D. Shi, X.-Q. Zhou et al., "In vitro and in vivo protective effect of arginine against lipopolysaccharide induced inflammatory response in the intestine of juvenile Jian carp (Cyprinus carpio var. Jian)," Fish \& Shellfish Immunology, vol. 42, no. 2, pp. 457-464, 2015.

[26] J. Günther, K. Esch, N. Poschadel et al., "Comparative kinetics of Escherichia coli- and Staphylococcus aureus-specific activation of key immune pathways in mammary epithelial cells demonstrates that $S$. aureus elicits a delayed response dominated by interleukin-6 (IL-6) but not by IL-1A or tumor necrosis factor alpha," Infection and Immunity, vol. 79, no. 2, pp. 695-707, 2011.

[27] S. Lapointe, A. Brkovic, I. Cloutier, J.-F. Tanguay, J. P. Arm, and M. G. Sirois, "Group V secreted phospholipase $A_{2}$ contributes to LPS-induced leukocyte recruitment," Journal of Cellular Physiology, vol. 224, no. 1, pp. 127-134, 2010.

[28] C. M. Calkins, D. D. Bensard, J. K. Heimbach et al., "L-Arginine attenuates lipopolysaccharide-induced lung chemokine production," The American Journal of Physiology-Lung Cellular and Molecular Physiology, vol. 280, no. 3, pp. L400-L408, 2001.

[29] P. P. Tak and G. S. Firestein, "NF- $\kappa$ B: a key role in inflammatory diseases," The Journal of Clinical Investigation, vol. 107, no. 1, pp. 7-11, 2001.

[30] S.-T. Lin, Y. Wang, Y. Xue, D.-C. Feng, Y. Xu, and L.-Y. Xu, "Tetrandrine suppresses LPS-induced astrocyte activation via modulating IKKs-I $\kappa \mathrm{B} \alpha-\mathrm{NF}-\kappa \mathrm{B}$ signaling pathway," Molecular and Cellular Biochemistry, vol. 315, no. 1-2, pp. 41-49, 2008.

[31] R. Checker, S. K. Sandur, D. Sharma et al., "Potent antiinflammatory activity of ursolic acid, a triterpenoid antioxidant, is mediated through suppression of NF- $\kappa \mathrm{B}, \mathrm{AP}-1$ and NF-AT," PLoS ONE, vol. 7, no. 2, Article ID e31318, 2012.

[32] S. Aggarwal, H. Ichikawa, Y. Takada, S. K. Sandur, S. Shishodia, and B. B. Aggarwal, "Curcumin (diferuloylmethane) downregulates expression of cell proliferation and antiapoptotic and metastatic gene products through suppression of $\mathrm{I} \kappa \mathrm{B} \alpha$ kinase and Akt activation," Molecular Pharmacology, vol. 69, no. 1, pp. 195-206, 2006.

[33] K.-C. Lee, H.-H. Chang, Y.-H. Chung, and T.-Y. Lee, "Andrographolide acts as an anti-inflammatory agent in LPSstimulated RAW264.7 macrophages by inhibiting STAT3mediated suppression of the NF- $\kappa \mathrm{B}$ pathway," Journal of Ethnopharmacology, vol. 135, no. 3, pp. 678-684, 2011.

[34] D. Verma, E. Särndahl, H. Andersson et al., “The Q705K polymorphism in NLRP3 is a gain-of-function alteration leading to excessive interleukin-1 $\beta$ and IL-18 production," PLoS ONE, vol. 7, no. 4, Article ID e34977, 2012. 
[35] C. Baylis, "Nitric oxide deficiency in chronic kidney disease," The American Journal of Physiology -Renal Physiology, vol. 294, pp. F1-F9, 2008.

[36] G. Wu, F. W. Bazer, T. A. Davis et al., "Arginine metabolism and nutrition in growth, health and disease," Amino Acids, vol. 37, no. 1, pp. 153-168, 2009.

[37] H. Y. Chung, E. K. Lee, Y. J. Choi et al., "Molecular inflammation as an underlying mechanism of the aging process and agerelated diseases," Journal of Dental Research, vol. 90, no. 7, pp. 830-840, 2011.

[38] A. Sierra, J. Navascués, M. A. Cuadros et al., "Expression of inducible Nitric Oxide Synthase (iNOS) in microglia of the developing quail retina," PLOS ONE, vol. 9, no. 8, Article ID e106048, 2014.

[39] Y. He, L. Franchi, and G. Núñez, “The protein kinase PKR is critical for LPS-induced iNOS production but dispensable for inflammasome activation in macrophages," European Journal of Immunology, vol. 43, no. 5, pp. 1147-1152, 2013.

[40] T. Xue and Y. Q. Zhang, "Protedive effects of L-Arginine against immature myocardial ischemiareperfusion injury," Chinese Journal of Clinical Rehabilitation, vol. 8, pp. 8210-8211, 2005.

[41] M. Colasanti, T. Persichini, M. Menegazzi et al., "Induction of nitric oxide synthase mRNA expression. Suppression by exogenous nitric oxide," Journal of Biological Chemistry, vol. 270, no. 45, pp. 26731-26733, 1995.

[42] R. Katso, K. Okkenhaug, K. Ahmadi, S. White, J. Timms, and M. D. Waterfield, "Cellular function of phosphoinositide 3kinases: implications for development, immunity, homeostasis, and cancer," Annual Review of Cell and Developmental Biology, vol. 17, pp. 615-675, 2001.

[43] S. Wullschleger, R. Loewith, and M. N. Hall, "TOR signaling in growth and metabolism," Cell, vol. 124, no. 3, pp. 471-484, 2006.

[44] T. Krakauer, "PI3K/Akt/mTOR, a pathway less recognized for staphylococcal superantigen-induced toxicity," Toxins, vol. 4, no. 11, pp. 1343-1366, 2012.

[45] T. Weichhart and M. D. Säemann, "The PI3K/Akt/mTOR pathway in innate immune cells: emerging therapeutic applications," Annals of the Rheumatic Diseases, vol. 67, no. 3, pp. iii70-iii74, 2008.

[46] S. Xie, M. Chen, B. Yan, X. He, X. Chen, and D. Li, "Identification of a role for the PI3K/AKT/mTOR signaling pathway in innate immune cells," PLoS ONE, vol. 9, no. 4, Article ID e94496, 2014.

[47] J. Peltier, A. O’Neill, and D. V. Schaffer, "PI3K/Akt and CREB regulate adult neural hippocampal progenitor proliferation and differentiation," Developmental Neurobiology, vol. 67, no. 10, pp. 1348-1361, 2007.

[48] L. Ojeda, J. Gao, K. G. Hooten et al., "Critical role of $\mathrm{PI} 3 \mathrm{k} / \mathrm{Akt} / \mathrm{GSK} 3 \beta$ in motoneuron specification from human neural stem cells in response to FGF2 and EGF," PLoS ONE, vol. 6, no. 8, Article ID e23414, 2011.

[49] S. D. S. Mendes, A. Candi, M. Vansteenbrugge et al., "Microarray analyses of the effects of NF- $\kappa \mathrm{B}$ or PI3K pathway inhibitors on the LPS-induced gene expression profile in RAW264. 7 cells: synergistic effects of rapamycin on LPS-induced MMP9overexpression," Cellular signalling, vol. 21, no. 7, pp. 1109-1122, 2009.

[50] M. Guha and N. Mackman, "The phosphatidylinositol 3-kinaseAkt pathway limits lipopolysaccharide activation of signaling pathways and expression of inflammatory mediators in human monocytic cells," The Journal of Biological Chemistry, vol. 277, no. 35, pp. 32124-32132, 2002.

[51] W.-J. Zhang, H. Wei, T. Hagen, and B. Frei, " $\alpha$-Lipoic acid attenuates LPS-induced inflammatory responses by activating the phosphoinositide 3-kinase/Akt signaling pathway," Proceedings of the National Academy of Sciences of the United States of America, vol. 104, no. 10, pp. 4077-4082, 2007.

[52] E. Lorne, X. Zhao, J. W. Zmijewski et al., "Participation of mammalian target of rapamycin complex 1 in toll-like receptor 2- and 4-induced neutrophil activation and acute lung injury," American Journal of Respiratory Cell and Molecular Biology, vol. 41, no. 2, pp. 237-245, 2009.

[53] C. F. Fortin, A. Cloutier, T. Ear et al., "A class IA PI3K controls inflammatory cytokine production in human neutrophils," European Journal of Immunology, vol. 41, no. 6, pp. 1709-1719, 2011.

[54] K. Hinz, P. M. O’Connor, T. Huppertz, R. P. Ross, and A. L. Kelly, "Comparison of the principal proteins in bovine, caprine, buffalo, equine and camel milk," Journal of Dairy Research, vol. 79, no. 2, pp. 185-191, 2012.

[55] S. Schmitz, M. W. Pfaffl, H. H. D. Meyer, and R. M. Bruckmaier, "Short-term changes of mRNA expression of various inflammatory factors and milk proteins in mammary tissue during LPSinduced mastitis," Domestic Animal Endocrinology, vol. 26, no. 2, pp. 111-126, 2004. 


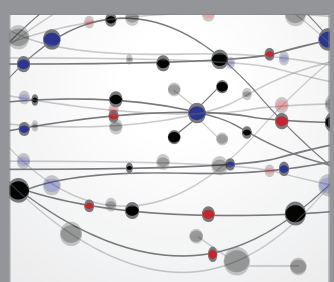

The Scientific World Journal
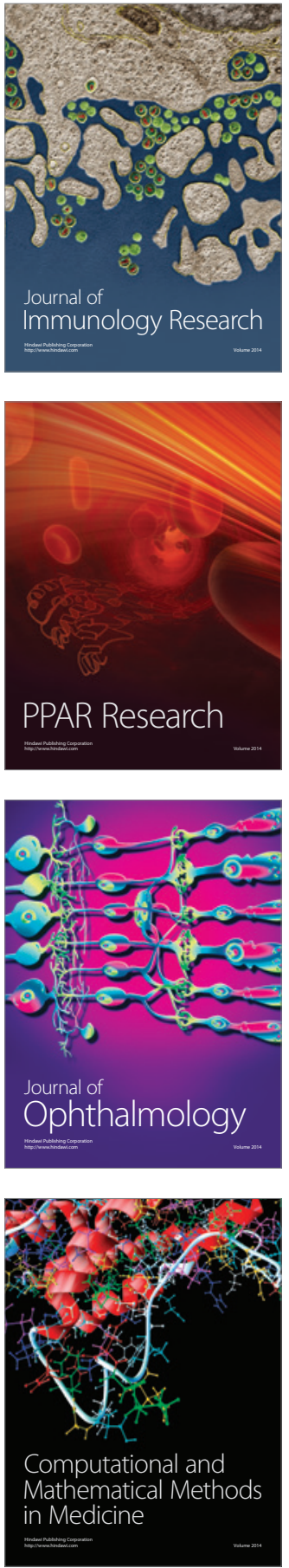

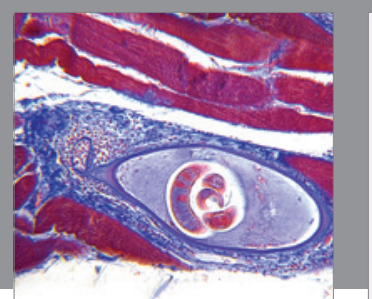

Gastroenterology Research and Practice

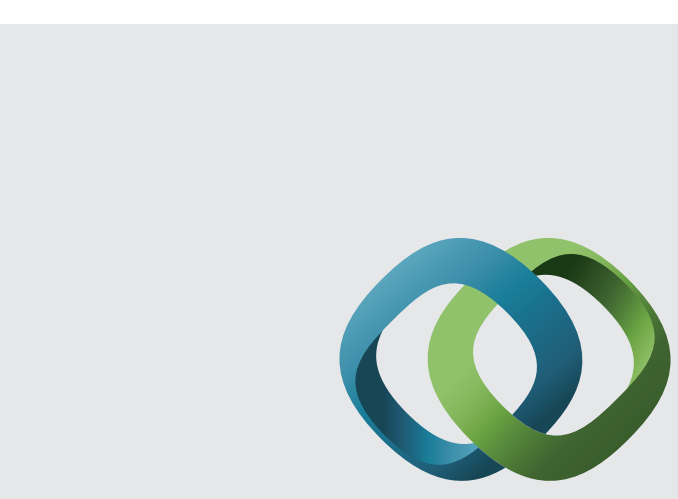

\section{Hindawi}

Submit your manuscripts at

http://www.hindawi.com
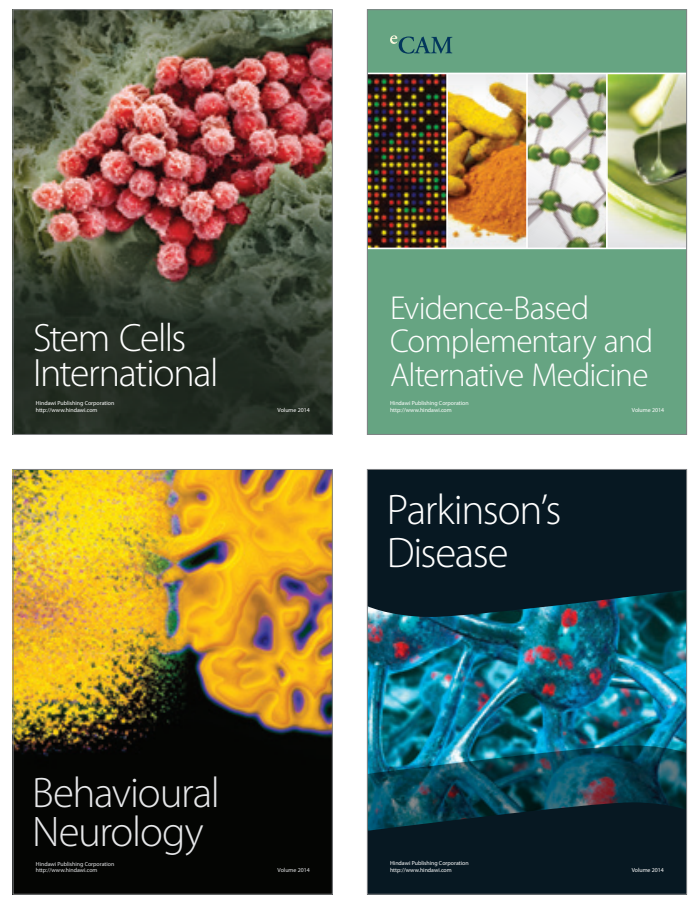
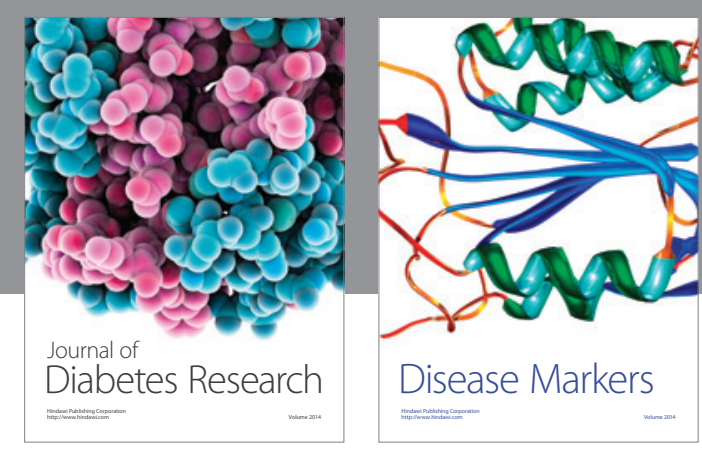

Disease Markers
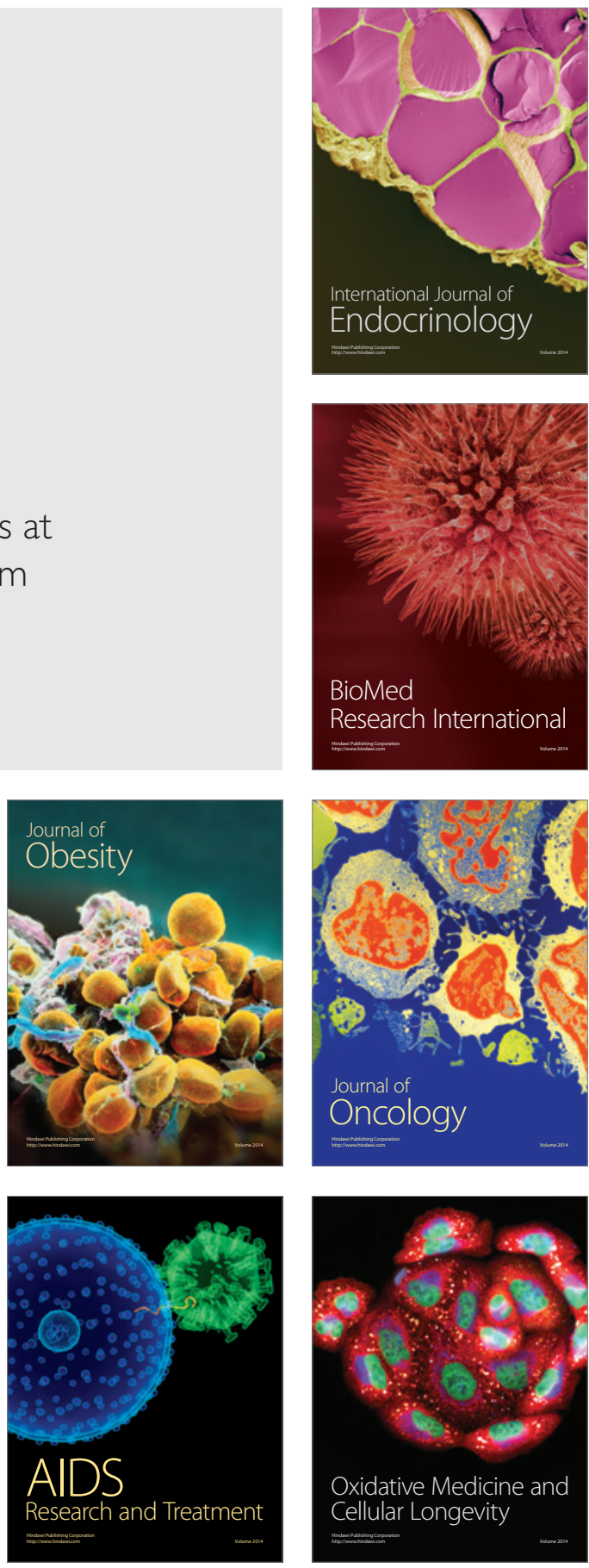